Acta vet. scand. 1989, 30, 235-237.

Brief Communication

\title{
Vomitoxin and Amino Acid Supplements in Rat Feed
}

In Finland grain has during some years contained considerable amounts of mycotoxins depending on the weather conditions, harvesting and preservation methods. The most common of these mycotoxins are Fusariumtoxins: zearalenone and trichotechenes. The trichotechene group is large, but only a few of the toxins are of practical interest in that they cause health disorders to farm animals. The most common toxin of the trichotechenes is deoksinivalenol or vomitoxin (DON), which causes, especially in pigs, vomiting and reduction in feed palatability.

The fusarium toxins are usually very resistent to outer factors. However, the trichotechenes can disappear from feed during storage (Karppanen et al. 1985). This is assumed to be the effect of amino acids or other compounds containing SH- or thiol groups in feed (Smith \& Moss 1985).

The harvest of 1984 contained vomitoxin at a particularly abundant level. The oats used at the Department of Animal Hygiene, College of Veterinary Medicine, contained 3-18 $\mathrm{mg} / \mathrm{kg}$. The grain contained also $0.8-0.9$ $\mathrm{mg} / \mathrm{kg}$ zearalenone toxin and traces of other trichotechenes: 3 AcDON, nivalenol, diacetoxyscirpenol. Using the toxin containing oats, two series of experiments were conducted with young female rats to establish the effect of some additonal amino acids on the growth of the rats, feed palatability and feed to gain ratio.

In the first series of experiments, the level of toxin was high in the experimental feed ( $80 \%$ oats, $20 \%$ commercial rat feed), averaging $13 \mathrm{mg} / \mathrm{kg}$. Lycine $0.55 \mathrm{~g} / \mathrm{kg}$ and me- thionine $5.5 \mathrm{~g} / \mathrm{kg}$, were used as amino acid supplements. The lycine was added as a $5 \%$ water solution and the methionine as a $4.2 \% \mathrm{HCl}$-solution of $50 \% \mathrm{DL}$-methionine. Toxin free feed, with and without lycine or methionine supplement, was used as control feed. In the second series of experiments, the level of toxin was lower in the feed, on an average $4.5 \mathrm{mg} / \mathrm{kg}$. In addition to lycine and methionine, cystine was also used at a level of $1.1 \mathrm{~g} / \mathrm{kg}$ and monohydrate of cysteine chloride at $5.5 \mathrm{~g} / \mathrm{kg}$. Cystine was added as 1 $\mathrm{N} \mathrm{NaOH}$ and cysteine as a $50 \%$ water solution. The moisture content of the experimental feed stuffs was $20 \%$.

The female rats used were 35 days old. They were lighter $(105 \mathrm{~g})$ in the first experiment than in the second $(125 \mathrm{~g})$. The rats received a daily ration of feed that was thought to be adequate. The uneaten feed was weighed daily. The palatability and feed to gain ratio was based on the total consumption and growth rate.

The feed to gain ratio was the same for toxin free stuffs in both experimental series $(0.14 \mathrm{~g}$ feed/g growth). Feed consumption and growth rate of the rats was lower in experiment 2 than in experiment 1 . The probable explanation to this is that the rats in experiment 2 were heavier and therefore, their growth ability was smaller.

The palatability, growth and feed to gain ratio in the toxin contaminated feed experiments $(13 \mathrm{mg} / \mathrm{kg}$ and $4.5 \mathrm{mg} / \mathrm{kg}$ feed) were worse than in experiments with toxin free feed stuffs. The decrease in the palatability $(13.7 \%$ and $8.5 \%)$ changed in the same di- 
Table 1. The effect of some amıno acids on the palatability of the experimental feed stuffs, growth of the rats and feed to gain ratio.

\begin{tabular}{|c|c|c|c|c|c|c|c|}
\hline \multirow[b]{2}{*}{ Quality of feed stuffs } & \multicolumn{3}{|c|}{$\begin{array}{c}\text { Exp serıes I } \\
\text { (toxın in feed } 13 \mathrm{mg} \text { DON/kg) }\end{array}$} & \multicolumn{3}{|c|}{$\begin{array}{c}\text { Exp series } 2 \\
\text { (toxın in feed } 4.5 \mathrm{mg} \mathrm{DON} / \mathrm{kg} \text { ) }\end{array}$} & \multirow[b]{2}{*}{ Note } \\
\hline & $\begin{array}{c}\text { Feed con- } \\
\text { sumption } \\
\% \\
(420 \mathrm{~g}= \\
100)\end{array}$ & $\begin{array}{c}\text { Growth } \\
\% \\
(58,1 \mathrm{~g}= \\
100)\end{array}$ & $\begin{array}{c}\text { Feed to } \\
\text { galn ratıo } \\
\% \\
(0,14 \mathrm{~g} \\
\text { growth } / \mathrm{g} \\
\text { feed }=100)\end{array}$ & $\begin{array}{c}\text { Feed con- } \\
\text { sumption } \\
\% \\
(416 \mathrm{~g}= \\
100)\end{array}$ & $\begin{array}{l}\text { Growth } \\
\% \\
(56,1 \mathrm{~g}= \\
100)\end{array}$ & $\begin{array}{c}\text { Feed to } \\
\text { gain ratıo } \\
\% \\
(0,14 \mathrm{~g} \\
\text { growth/g } \\
\text { feed }=100)\end{array}$ & \\
\hline \multirow{3}{*}{$\begin{array}{l}\text { Toxın free } \\
\begin{aligned}, \quad+\text { lysine } \\
, \quad+\text { methıonıne }\end{aligned}\end{array}$} & $100^{\mathrm{a}}$ & 100 & 100 & 100 & 100 & 100 & \multirow{8}{*}{$\begin{array}{l}\text { All fooda } \\
\text { consumed, the } \\
\text { consumption } \\
(420 \mathrm{~g}) \\
\text { probably } \\
\text { a little too } \\
\text { small and the } \\
\text { figures }^{\mathrm{b}} \text { too big }\end{array}$} \\
\hline & $100^{\mathrm{a}}$ & $124^{*}$ & 124 & & & & \\
\hline & $100^{\mathrm{a}}$ & 111 & 111 & & & & \\
\hline \multirow{5}{*}{$\begin{array}{l}\text { Toxın contamınated } \\
\begin{array}{l}, \quad+\text { lycıne } \\
, \quad+\text { methıonıne } \\
, \quad+\text { cystın } \\
, \quad+\text { cysteıne }\end{array}\end{array}$} & $86^{b}$ & 84 & 97 & 91 & 45 & 50 & \\
\hline & $82^{b}$ & $20^{* * *}$ & 25 & 90 & 44 & 47 & \\
\hline & $93^{b}$ & $48^{*}$ & 51 & 95 & 68 & 69 & \\
\hline & & & & 93 & 38 & 41 & \\
\hline & & & & 91 & 38 & 42 & \\
\hline${ }^{*} \mathrm{p}=<0,02$ & & aber of & ts per groups & 8 & & & \\
\hline$* * * \mathrm{p}=<0,001$ & & ration of & xperiment & 28 days & & & \\
\hline
\end{tabular}

rection with the amounts of toxin $(13.0 \mathrm{mg}$ and $4.5 \mathrm{mg} / \mathrm{kg}$ ). But the growth of the rats and feed to gain ratio was lower with the feed that had less toxin than with the feed that had a higher toxin content. The weight difference at the beginning of the experiment might have influenced the results.

The effect of some amino acid supplements was surprising. In experiment 1 both amino acid supplements (lycine and methionine), especially lycine, increased even further the negative effect of the toxic feed. In the toxin free feed, both amino acid supplements, especially lycine, increased the positive effect of the feed.

In experiment 2 , the effect of lycine, cysteine and cystine on the growth and feed to gain ratio with toxic feed was similar, but considerably weaker. The effect of the methionine supplement was positive.

In view of these results, it seems that amino acids together with toxins can form even more toxic compounds in feed stuffs. The difference between the experiments might be that the amount of toxin was considerably lower in experiment 2 , with a decreased formation of harmful compounds as a result.

These observations, however, need more research. There is a need to clarify the possible effect of small amounts of the other trichotechenes and zearalenon that were found in these vomitoxin containing feed stuffs.

These studies indicate the necessity of biologic experiments in research concerning detoxification mechanisms.

K Kallela, I Saastamoinen and $H$ Saloniem Department of Anımal Hygiene, College of Veterınary Medicine, Helsinki, Finland.

A Rizzo,

Natıonal Veterinary Instıtute, Helsinki, Finland. 


\section{References}

Karppanen E, Rızzo A, Berg S, Sundfors E, Aho $R$ Fusarium mycotoxins as a problem in Finnısh feeds and cereals. J. Scı. Agric. Soc. Finl. $1985,57,195-206$
Smith JE, Moss MO Mycotoxins, Formation, Analysis and Significance. Wiley \& Sons LTD Chichester-New York-Brisbane-Toronto-Sıngapore 1985.

(Recelved May 2, 1989, accepted June 21, 1989)

Reprınts may be requested from: K. Kallela, Department of Anımal Hygiene, College of Veterınary Medıcıne, Hämeentıe 57, SF-00550 Helsınkı, Fınland 


